\title{
BETTER BUSINESS BUREAU ACTIVITIES IN AID OF THE TIME PURCHASER
}

\author{
EDWARD L. GREENE*
}

Consumer complaints made to Better Business Bureau executives against dealers who sell on time payments are the result of various causes. The most common complaints are against dealer deception-sometimes downright trickery. Occasionally it is impossible to show that the law has been violated, yet nevertheless, from our experience, we know that some dealers have set out deliberately to trap their customers. Thus enmeshed in legal contractual relationships, the victims must have assistance to avoid serious losses. Unfortunately, they are frequently dependent upon the questionable leniency of ruthless schemers which is, to say the least, forcing them into accepting hard bargains.

Of course, there are some participants of time payment purchases who find themselves in trouble because of their over-reaching their ability to meet instalments as they come due. Some complainants are welshers who attempt to obtain the services of the Bureaus to pull their chestnuts out of the fire.

It is well to bear in mind, moreover, that in any discussion of the practices involved in time payment sales plans there are countless instalment sales that are mutually satisfactory to buyers and sellers. We are without the facilities to make a careful survey of unfair time payment practices which affect the consumer, but from what we have learned from consumer complaints we believe that there is ample need for greater consumer protection.

Generally speaking, Bureau executives report that most of the complaints they receive involve the automobile, automobile accessory, furniture, radio and jewelry businesses. While there is no doubt that unfair transactions occur in the sale of new automobiles, it seems to us that practices in the sale of used cars are more serious.

Complaints indicate that many people do not understand that there is no standard financing charge. Where buyers have questioned the interest charges, the salesmen are known to have replied that they are the usual nominal charges. Later, the buyer discovers that they are excessive. Some used car buyers are induced to sign time payment papers in blank. Of course, this carelessness leaves them wide open for any

- A.B., I908, University of Pennsylvania. General Manager, National Better Business Bureau, since 1925. Previously General Manager, Boston and Cleveland Better Business Bureaus. Author of numerous articles on unfair trade practices. 
chicanery that unscrupulous dealers can devise. In some instances used car dealers advertise "No Down Payment" but require chattel mortgages on furniture before consummating sales.

One Bureau executive reports: "Our primary complaints in this field have been against automobile accessory and radio dealers taking liens on cars and then attaching them. One case which is not typical, but which illustrates the practice, was of a colored boy who owed $\$ 2.00$ on a tire for his car. His car was attached and he was forced to pay a $\$ 15$ repossessing fee, the balance on the tire and a $\$ 2.00$ storage fee for his car."

Another Bureau executive reports: "Some cases have come to our attention wherein the buyers were quoted a definite price as a financing cost only to find upon completion of the sale that the total financing charge was sometimes two or three times as much as what had been represented to them. When the purchasers learned of these discrepancies and refused to make further payments, the financing companies then went through the regular procedure of repossessing. The most unfortunate part of some of these cases has been that the purchasers had signed conditional bills of sale before the terms were written into their contracts. One dealer had a further hold on his victims even if his prospects did not go through with the conditional bill of sale. Many complainants alleged that when they had old cars and called at the dealer's place of business to try out the cars they were contemplating purchasing, they were asked to leave their old cars while they tried the dealer's. At the same time, they were asked to sign a paper which was represented to be a receipt to show they were trying out the dealer's cars but which actually turned out to be releases on their own cars. During the period they were testing the dealer's cars their own cars were removed, and when they complained the dealer pointed out to them that they had signed releases on their cars and in some cases had actually signed orders to purchase cars using their old cars as down payments."

We have a report on a tire company that makes short-term contracts and renews them for a fee. Some people have complained that after several years of paying on their contracts they still owe more than the original purchase price.

We are advised that furniture dealers are exercising a more careful check-up before they will sell on time payment plans. The reason for this care is due to losses resulting from repossessing. However, when credit has been established some furniture dealers are not above trying sharp practices. A case in point is of a buyer who contracted to pay $\$ 1,000$ for some furniture. When the amount due was paid the dealer induced the customer to buy a $\$$ ioo radio. Before the radio was paid for the buyer lost his position and was unable to continue the instalments. The buyer claimed that, unknown to him, the purchase of the radio was placed in the same account as his paid up furniture, and for failing to meet instalments on his radio, he was threatened with a loss of his household furniture as well as his radio.

Interest charges sometimes amount to much more than is claimed by the dealer. 
A case reported involved the purchase of a piano for which the buyer contracted to pay \$545. He was told that an interest charge of 6 per cent would be made. But when he started paying the "accommodation" charge, it was for $\$ 2.48$ a month until he completed his contract. He paid this charge of $\$ 2.48$ a month for three years, sometimes missing a payment on the principal but always paying the carrying charge. At the time the case was reported, the customer had been paying on his contract for three years and had reduced the principal to $\$ 7$ I. But, of course, the $\$ 2.48$ a month financing charge continued.

Instalment houses as a general rule advertise "Easy Credit Terms." Many prospective customers are-induced to make down payments before their credit is established. Unscrupulous dealers who so advertise and who subsequently refuse to extend credit have been known also to refuse to refund the down payments. Instead, they insist that the down payments be traded in on cash purchases. Victims of this scheme are forced to buy something that they can get along without and what they do obtain for their money is in most instances excessively priced. In one such case the proprietor of the store was prosecuted on the charge of larceny by trick.

In states where employees are not protected against the abuses applicable to assigning their wages, they are likely to be exploited.

The wage assignment made for goods has, in the past, been used in a proper manner by a number of concerns. Unfortunately, it has also been used by a type of dealer relying upon high-pressure selling methods and questionable practices to extract the "last dollar possible" from a customer. These assignments are usually made in haste, the purchasers frequently believing that they are merely signing for the delivery of the goods. They may not know the seriousness, nor appreciate the importance, of an assignment of future wages. They are often signed by persons misled by verbal statements of the salesman which are not included in the printed agreement; and the agreement is frequently printed in such small type as to require a magnifying glass to read it, and to understand the complicated phrasing would require a "Philadelphia lawyer." Then the assignment is kept in escrow until its use is needed for collection purposes. In any case, where dispute arises in regard to tho goods delivered by the dealer, the purchaser is practically helpless. He must meekly submit to unjust treatment, or face the possibility of his employer being called upon to pay on the wage assignment.

Whenever notices of an assignment are served, many employers have promptly discharged the employees without investigating the circumstances connected with the cases. They resent being compelled, without their knowledge and consent, to pay a third party one-quarter of an employee's weekly wages. The system also involved considerable expense for the employer. The assignment ran against "any person by whom I am now employed or may be employed." It required no acceptance by the employer; he had no discretion and was obliged to pay. To avoid the duty of being a compulsory bill collector, he often dismissed the employee or told him to pay the 
dealer direct. Thus the employee had little chance of successfully resisting unjust demands by the holder of an assignment.

There are a number of cases on record with the Better Business Bureaus where customers signed wage assignments in connection with a purchase of furniture, etc., on the partial payment plan. In these cases of complaint, it is set forth that they failed to secure the furniture which they purchased, but that cheaper and inferior merchandise was substituted. When they refused to complete their payments, and made complaints, they were threatened with wage assignments unless payments were made in accordance with the terms agreed upon. Many employees, fearful of the attitude of their employers, have, in this way, been victimized by unscrupulous dealers.

The person who received the assignment knew its value. It was not only good security, but was a club over the head of the man who gave it. Employees submitted to unreasonable terms, to unfair treatment, and to additional costs, because of their fear of the attitude of their employer if a notice of the wage assignment was served on him. Consequently, a family in such a predicament paid excessive and exorbitant charges for credit out of all reason to the actual cost of this service.

The unfair use of the wage assignment is confined to a group of unscrupulous dealers who have continued in business by abusing the confidence of the public, chiefly workers of small means. The financial condition of the people involved, and the attitude of some large employers, indicate that the remedy did not lie in any court procedure. In fact, the damage was caused before an attorney could be employed or court action commenced.

While no doubt there are reliable dealers who include an assignment of wages in their instalment sales contracts, the use of such contracts by scheming dealers often leads to misfortune and great grief to their victims. The wage assignment also reduces the necessity of credit checking when the prospective buyer is employed in a position that indicates regular employment. Consequently, most of the unscrupulous dealers direct their claims and efforts to this class of wage-earner.

There have been many schemes devised to sell jewelry. One of the most vicious reported to us was practiced by salesmen who induced small salaried employees, while at their places of employment, to take cheap jewelry home for "examination." The salesmen stated that if it was not satisfactory they would return the following week and take it back. They required the recipients, however, to sign "receipts," which were in fact bills of sale, and wage assignments to be served on their employers in the event of failure to pay. The salesmen never returned and no effort was made to collect directly from the buyers. In due course, the wage assignments would be served on the employers.

When customer complaints involving time payments are brought to the attention of Bureau executives, they proceed to investigate all the circumstances leading up to the complaints. The Bureau manager acts as a neutral third party mediating the 
difficulty so as to try to protect the interest of the other two. When this procedure is not successful and the Bureau manager believes the customer's complaint is justified, he may refer the customer to the Legal Aid Society or to some law-enforcing body, whichever, in his judgment, will prove more helpful.

It is, of course, customary for Bureau executives to keep records of complaints brought to their attention. This practice will usually provide the evidence to point out unscrupulous dealers. The accumulated evidence thus obtained will be presented to a law-enforcing body. It is also the practice of many Bureau managers to issue publicity prepared to reach the public which names unfair dealers and outlines the practices which are detrimental to public interest.

The Better Business Bureaus, of course, are amenable to the law and consequently must act in accordance with the law. But there are numerous occasions when adjustments are obtained by Bureau executives for parties to complaints that are the result of misunderstandings. Complaints cleared up by this procedure are helpful both to the public and honest dealers.

Bureau executives examine complaints from the customer viewpoint because it is obvious that if a dealer deceives the public he is likewise using unfair competition. Unfair competition might be difficult to prove in some cases of fraud, but in businesses where time payments are used, this difficulty is not a factor.

The interpretation of the Retail Code which requires that advertising offering time payment sales plans must also include a notice of financing costs when they are charged, ${ }^{1}$ has proved very helpful in eliminating complaints in those communities where the Retail Code is enforced.

This tends to demonstrate that, if the public is put on notice that financing charges must be paid if purchases are to be made on time payment plans, customers will enter into such transactions with a better understanding of their responsibilities and exercise a greater degree of self-protection, and make better credit risks for those with whom they do business.

Bureau publicity is distributed in bulletins, newspaper releases and radio broadcasts. The publicity urges consumers who believe they have been cheated to report their experience to the Bureau. In communities where this program is actively carried out, unscrupulous dealers become known and in many instances have been forced to change their tactics. Overloading charges, however, may not be discovered if they are adroitly sold, and doubtless there are many unfair and deceptive sales that are made that Bureau managers never hear about.

${ }^{1}$ The Code of Fair Competition for the Retail Trade provides: "No retailer shall use advertising . . . which ... misrepresents... credit terms." Art. IX, $\$ \mathbf{r}$ (a). The following official interpretation of the application of this provision to the advertising of time payment plans was issued June 26, 1934. "It shall be an unfair trade practice, under Article IX, Section I (a) of the Code for a retailer to advertise or offer for sale any merchandise with a statement or sepresentation that the merchandise may be purchased on any deferred payment plan, of whatever nature, without charge for such deferred payment, interest, services, privilege, or other comparable designation, when in fact discounts from quoted or marked prices are given on identical goods sold for cash or when differentials between prices for cash and prices fór installment payment are quoted, marked, or made available for identical merchandise, at any time during the period in which such merchandise is on sale or offered for sale." N. R. C. A. Rev. Bulletin TP-7. 